\title{
Responses of pubertal rabbits to dietary supplementation of ginger (Zingiber officinale rosc) rhizome powder
}

Ogbuewu*, I.P., Iwuji, T.C., Etuk, I. F., Ezeokeke, C.T., Okoli I.C. and Iloeje, M.U. Department of Animal Science and Technology, Federal University of Technology,

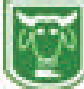

P.M.B.1526 Owerri, Nigeria.

*Corresponding author: dr.ogbuewu@gmail.com

\begin{abstract}
Seventy two (72) sexed crossbred rabbits aged 6 months were used to determine the effect of ginger rhizome powder (GRP) supplementation on reproductive organ and serum sex hormonal characteristics of pubertal rabbits. The experimental rabbits were divided into 2 treatment groups comprising 36 males and 36 females. Each group was divided into 4 dietary treatments $\left(B T_{1}, B T_{2}, B T_{3}\right.$ and $\left.B T_{4}\right)$ of 9 animals and replicated thrice with 3 animals per replicate in a completely randomized design (CRD). The animals were fed formulated

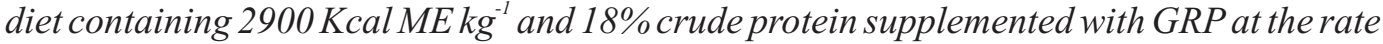
of $0,5,10$ and $15 \mathrm{~g} \mathrm{~kg}^{-1}$ feed respectively. Rabbits in each dietary group were fed $50 \mathrm{gms}$ of Guinea grass leaf meal containing 27.6\% CF (dry matter basis) occasionally as additional fibre sources. Feed and water were offered ad libitum and the study lasted for 10 weeks. Testosterone values of $B T_{2}\left(5.83 \mathrm{ng} \mathrm{mL}^{-1}\right)$ and $B T_{4}\left(6.28 \mathrm{ng} \mathrm{mL}^{-1}\right)$ and follicle stimulating hormone (FSH) levels of $B T_{3}\left(1.15 \mathrm{mIU} \mathrm{mL}^{-1}\right)$ were significantly influenced $(p<0.05)$ by ginger rhizome powder. Bucks on $B T_{3}$ and $B T_{4}$ had lower luteinizing hormone (LH) level than the BT, bucks. For the females, FSH and LH values ranged significantly $(p<0.05)$ from 0.90 to $2.05 \mathrm{mIU} m L^{-1}$ and 0.90 to $3.15 \mathrm{mIU} m L^{-1}$ respectively. The $17 \beta$ - estradiol and progesterone levels also ranged significantly $(p<0.05)$ from 166.35 to $175.05 \mathrm{pg} \mathrm{mL}^{-1}$ and 15.45 to $16.80 \mathrm{ng} \mathrm{mL}^{-1}$ respectively. Ovarian weight of rabbit on $B T_{3}$ was significantly $(p<0.05)$ higher than those on $B T_{1}$ but similar to those on $B T_{2}$ and $B T_{4}$ treatments. It was therefore concluded that the use of ginger rhizome powder in rabbit diets improved the weight of the ovary as well as enhances serum progesterone, estrogen and testosterone levels.
\end{abstract}

Keywords: Ginger, rabbits, ovary, testosterone, estrogen, progesterone

\section{Introduction}

High levels of production and efficient feed conversion are the needs of the modern animal industry which, to a certain extent, could be achieved by the use of specific nutritive and non nutritive feed additives. Antibiotic growth promoters have been included in livestock diets to promote growth, health and to maximize the genetic potentials of farm animals (Bozkurt et al., 2008). However, the development of drug resistant micro organisms in humans has compelled animal nutritionists and feed millers to search for alternative plant extracts as growth promoters in monogastric animals (Denli et al., 2003). Researchers (Denli et al., 2003) have identified several beneficial active ingredients in medicinal plants and herbs which play important roles in improving production and immune system of animals against diseases, and could be effectively utilized as natural growth promoters to replace antibiotics. These plants, spices and fruits include garlic, ginger, pepper and bitter kola, among others. Specifically, ginger has been extensively investigated 
and their properties documented (Zhang et al., 2009; Zhao et al., 2011). Ginger belongs to the family Zingiberanceae and also is a major crop grown primarily in China, India and Nigeria, and exported worldwide. Ginger leaves are linear, and the flowers are lemon green in colour. It is a well known herb widely used as a spice all over the world (Bartley and Jacobs, 2000) and in medical treatment for certain ailments in traditional medicine (Zhang et al., 2009). Ginger contains several phytochemical compounds which have biological activities such as antioxidation, antimicrobial and other pharmacological effects (Zhao et al., 2011).

This study was therefore; designed to examine the effect of dietary ginger rhizome powder supplementation on reproductive organ and sex hormone characteristics of pubertal rabbits.

\section{Materials and Methods}

This experiment was conducted at the Rabbit Unit of the Teaching and Research Farm, Department of Animal Science and Technology, Federal University of Technology, Owerri, Nigeria. Geographically, Imo State is located on latitude $4^{\circ} 4^{\prime}$ and $6^{\circ} 3^{\prime} \mathrm{N}$ and longitude $6^{\circ} 15^{\prime}$ and $8^{\circ} 15^{\prime} \mathrm{E}$. Fresh ginger rhizomes of the Indian cultivar Himachel pradesh were procured from National Root Crops Research Institute (NRCRI), Umudike, Abia State. The processing method used is according that described by Ogbuewu et al. (2013). Milled ginger rhizome powder was collected and stored in a polyethene bag for use in feed supplementation.

Experimental animals used in this study were 72 crossbred pubertal rabbits (36 males and 36 females), aged 6 months. The animals were housed 3 rabbits per cage in a
Table 1. Nutrient composition of the experimental diet

\begin{tabular}{ll}
\hline Nutrients & Percent $(\%)$ \\
\hline Crude protein & 18.00 \\
Ether extract & 6.00 \\
Crude fibre & 5.00 \\
Salt & 0.30 \\
Calcium & 1.00 \\
Phosphorus & 0.45 \\
Lysine & 0.75 \\
Methionine & 0.35 \\
Metabolisable energy & 2900 \\
(Kcal/kg) & \\
\hline
\end{tabular}

two tier hutch with wooden / wire mesh floor. A 14 -day pre -treatment period was used to acclimatize the animals to the experimental procedure. The 72 sexed rabbits were divided into two major groups comprising 36 males and 36 females. Each group was further divided into 4 groups $\left(\mathrm{BT}_{1}, \mathrm{BT}_{2}, \mathrm{BT}_{3}\right.$ and $\left.\mathrm{BT}_{4}\right)$ of 9 rabbits each, replicated 3 times with 3 rabbits per replicate in a completely randomized design (CRD). The nutrient composition of the experimental diet is as presented in table 1 . The other 3 dietary groups were given the same diet as fed to the control groups, but supplemented with GRP at $5 \mathrm{~g}\left(\mathrm{BT}_{2}\right), 10 \mathrm{~g}$ $\left(\mathrm{BT}_{3}\right)$ and $15 \mathrm{~g}\left(\mathrm{BT}_{4}\right)$ per kilogram feed. Rabbits in each dietary group were fed $50 \mathrm{gms}$ of Guinea grass leaf meal containing $27.6 \% \mathrm{CF}$ and $6.05 \%$ ash on dry matter basis occasionally as additional fibre sources. Feed and water were offered ad libitum and the study lasted for 10 weeks.

The blood samples used for this study were taken from marginal ear vein of the experimental rabbits at the end of the trial, between the hours of 8 am and 9 am before feeding. The blood samples were collected into a set of sterile plastic bottles and allowed to coagulate to produce sera for 
hormonal analyses. The test for hormonal parameters in the blood serum (Testosterone, luteinizing hormone (LH), follicle stimulating hormone (FSH), progesterone, and estrogen) were carried out with the aid of the tube based enzyme immunoassay (EIA) method. The protocol used for the hormone assay was according to the method of Micaleft et al. (1995) as described for the kit (BioCheck ELISA Assay, USA).

At the end of the 10 weeks feeding trial, one female rabbit from each of the replicates, making three per treatment, was fasted for 12 hours, weighed, slaughtered and dissected following standard procedure (Karbe and Skottke, 1985). The ovaries were collected, trimmed free of fats and adhering connective tissues. The ovary organ was weighed with an electronic precision balance (Model L2200P) and the weights expressed as percentages of live body weight. The histopathological examination of the ovarian tissue was carried out at the Histopathology Laboratory, Federal Medical Centre, Owerri, as described by Drury and Wallington(1976).

The data obtained were subjected to Analysis of Variance (ANOVA) in a completely randomized design (CRD) using a computer software (SAS, 1999). Differences between means were separated using Duncan's New Multiple Range Tests (DNMRT (Steel and Torrie, 1980).

\section{Results and Discussion}

Data on male sex hormones profile of pubertal rabbits fed GRP supplemented diets are presented in Table 2. There were significant $(p<0.05)$ difference in FSH levels measured, these values however did not follow pattern. Bucks in $\mathrm{BT}_{1}$ recorded significantly $(\mathrm{p}<0.05)$ higher $\mathrm{LH}$ value $\left(0.65 \mathrm{mIU} \mathrm{mL}^{-1}\right)$ than bucks in $\mathrm{BT}_{3}(0.30$ $\left.\mathrm{mIU} \mathrm{mL} \mathrm{m}^{-1}\right)$ and $\mathrm{BT}_{4}\left(0.10 \mathrm{mIU} \mathrm{mL}^{-1}\right)$. The serum testosterone values ranged significantly $(\mathrm{p}<0.05)$ from 3.93 to $6.28 \mathrm{ng}$ $\mathrm{mL}^{-1}$. The serum testosterone values recorded in this study compared favourable with the range of 2.51 to $2.88 \mathrm{ng} \mathrm{mL}^{-1}$ reported for male rabbits fed coconut ash supplemented diets (Iwu et al., 2013). According to Osinowo (2006) and Ogbuewu et al. (2011), circulating testosterone in the male are produced primarily in the gonads under the influence of FSH and LH. The observed increase in testosterone levels of $\mathrm{BT}_{2}, \mathrm{BT}_{3}$ and $\mathrm{BT}_{4}$ bucks is an indication that ginger rhizome powder probably contains some androgenic analogue which acts on hypothalamus to stimulate testosterone release from the testes through the action of gonadotropin releasing hormone $(\mathrm{GnRH})$ and luteinizing hormone.

The effect of ginger rhizome powder supplemented diets on serum hormones profile of female rabbits are presented in Table 3. The LH values were found within the range of $0.90-3.15 \mathrm{mIU} \mathrm{mL}^{-1}$. The $\mathrm{LH}$ levels were negatively influenced $(p<0.05)$ by the treatments. The FSH values ranged significantly $(p<0.05)$ from 0.90 to 2.05 $\mathrm{mIU} \mathrm{mL}{ }^{-1}$. The progressive decline in FSH and $\mathrm{LH}$ values suggest that ginger rhizome powder supplementation reduces the serum circulating FSH and LH levels. Interestingly, the dose related decrease in LH level in the current study agrees with earlier reports of Kiuchi et al. (1982) in rats administered ginger powder. The dose related decrease in LH and FSH value of female rabbits observed in this study could also be an indication that some of the bioactive ingredient (s) contained in ginger may have negatively influenced the synthesis and release of these hormones 
into the blood. According to Osinowo (2006), the circulating LH in the female is responsible for maintaining normal plasma estradiol and progesterone concentration.

The concentrations of progesterone in the current work were within the range 15.45 to $16.80 \mathrm{ng} \mathrm{mL}^{-1}$. Rabbits fed diet supplemented with ginger rhizome powder at $5 \mathrm{~g} \mathrm{~kg}^{-1}$ feed showed a significant $(p<0.05)$ increase in the progesterone level as against the rabbits fed control and $\mathrm{BT}_{4}$ diets. The values increased with ginger rhizome powder supplementation at $5 \mathrm{~g} \mathrm{~kg}^{-1}$ feed (16.80 ng mL ${ }^{-1}$ ) but declined slightly at $10 \mathrm{~g} \mathrm{~kg}^{-1}$ feed (16.55 $\left.\mathrm{ng} \mathrm{mL}^{-1}\right)$ and $15 \mathrm{~g} \mathrm{~kg}^{-1}$ feed $\left(15.57 \mathrm{ng} \mathrm{mL}^{-1}\right)$. Also, $\mathrm{BT}_{2}$ and $\mathrm{BT}_{3}$ had higher $(p<0.05)$ serum $17 \beta$-estradiol levels compared to the groups fed $0 \mathrm{~g} \mathrm{~kg}^{-1}$ and $15 \mathrm{~g}$ $\mathrm{kg}^{-1}$ feed. Highest serum 173 - estradiol value was achieved in the group fed ginger rhizome powder diet at $10 \mathrm{~g} \mathrm{~kg}^{-1}$ supplementation rate. These results are in harmony with Hsia et al. (2007) who reported that administration of some medicinal plant extract in rabbit increased circulating $17 ß$-estradiol and progesterone level. Progesterone helps to regulate the oestrus cycle, prepare the female for conception and pregnancy (Osinowo,
2006). The increase in the concentration of blood $17 \beta$-estradiol with supplementation of ginger rhizome powder in this study could therefore be attributed in part to increased metabolic activity in the supplemented animals, probably induced by increased uptake and assimilation earlier recorded in these animals (Ogbuewu et al., 2010; Ogbuewu, 2012).

The results of the ovarian weight of female rabbits fed GRP supplemented diets are presented in figure 1 . The ovarian weight of $\mathrm{BT}_{3}$ females was significantly higher $(\mathrm{p}<0.05)$ than those of $\mathrm{BT}_{1}$ but similar to those on $\mathrm{BT}_{2}$ and $\mathrm{BT}_{4}$ treatments. From these results, supplementation of GRP at $5 \mathrm{~g}$ $\mathrm{kg}^{-1}$ feed, $10 \mathrm{~g} \mathrm{~kg}^{-1}$ feed and $15 \mathrm{~g} \mathrm{~kg}^{-1}$ feed increased the ovarian weight by $50 \%, 100 \%$ and $50 \%$, respectively relative to the control group. These findings were in agreement with the earlier reports of Bitto and Gemade (2001), and Ogbuewu (2008) that nutrition influences ovarian functions in rabbits. The significant increase in the ovarian weight of rabbits in $\mathrm{BT}_{3}\left(10 \mathrm{~g} \mathrm{~kg}^{-1}\right.$ feed) group over those in $\mathrm{BT}_{1}\left(0 \mathrm{~g} \mathrm{~kg}^{-1}\right.$ feed $)$ group was an indication that $10 \mathrm{~g} \mathrm{~kg}^{-1}$ feed could be the optimal inclusion level of GRP needed to enhance ovarian functions. The weights of

Table 2: Sex hormone characteristics of male rabbits fed graded levels of GRP supplemented diets

\begin{tabular}{llllll}
\hline Parameters & B $_{\mathbf{1}}$ & BT $_{\mathbf{2}}$ & BT $_{\mathbf{3}}$ & $\mathbf{B T}_{\mathbf{4}}$ & S.E.M \\
\hline FSH $\left(\mathrm{mIU} \mathrm{mL}^{-1}\right)$ & $0.50^{\mathrm{b}}$ & $0.70^{\mathrm{b}}$ & $1.15^{\mathrm{a}}$ & $0.95^{\mathrm{ab}}$ & 0.17 \\
LH $\left(\mathrm{mIU} \mathrm{mL}^{-1}\right)$ & $0.65^{\mathrm{a}}$ & $0.40^{\mathrm{ab}}$ & $0.30^{\mathrm{b}}$ & $0.10^{\mathrm{b}}$ & 0.04 \\
Testosterone $\left(\mathrm{ng} \mathrm{mL}^{-1}\right)$ & $3.93^{\mathrm{c}}$ & $5.83^{\mathrm{ab}}$ & $4.75^{\mathrm{bc}}$ & $6.28^{\mathrm{a}}$ & 0.02 \\
\hline
\end{tabular}

$\overline{\mathrm{a}, \mathrm{b}, \mathrm{c}}$ Means within a row with different superscripts differed significantly $(\mathrm{p}<0.05)$.

Table 3: Sex hormone characteristics of female rabbits fed graded levels of GRP supplemented diets.

\begin{tabular}{llllll}
\hline Parameters & BT $_{1}$ & BT $_{\mathbf{2}}$ & BT $_{3}$ & BT $_{4}$ & SEM \\
\hline FSH $\left(\mathrm{mIU} \mathrm{mL}^{-1}\right)$ & $2.05^{\mathrm{a}}$ & $1.95^{\mathrm{a}}$ & $1.40^{\mathrm{ab}}$ & $0.90^{\mathrm{b}}$ & 0.17 \\
$\mathrm{LH}\left(\mathrm{mIU} \mathrm{mL}^{-1}\right)$ & $3.15^{\mathrm{a}}$ & $1.70^{\mathrm{b}}$ & $1.35^{\mathrm{bc}}$ & $0.90^{\mathrm{c}}$ & 0.24 \\
$17 ß$-estradiol $\left(\mathrm{pg} \mathrm{mL}^{-1}\right)$ & $166.35^{\mathrm{b}}$ & $174.85^{\mathrm{a}}$ & $175.05^{\mathrm{a}}$ & $166.90^{\mathrm{b}}$ & 1.70 \\
Progesterone $\left(\mathrm{ng} \mathrm{mL}^{-1}\right)$ & $15.45^{\mathrm{b}}$ & $16.80^{\mathrm{a}}$ & $16.55^{\mathrm{ab}}$ & $15.57^{\mathrm{b}}$ & 0.21 \\
\hline
\end{tabular}

${ }^{\mathrm{abc}}$ Means within a row with different superscripts differed significantly $(\mathrm{p}<0.05)$ 
the ovary recorded in this study compared favourably with the value $(0.05-0.12 \mathrm{~g})$ reported by Osuagwu (2004) and Ogbuewu (2008) in growing rabbits. The significantly higher ovarian weight recorded in $\mathrm{BT}_{3}$ corresponds with the highest estradiol value. This confirms earlier report Iwu et al. (2013) of increased metabolic activity of the ovary with increased nutrient uptake and assimilation in growing rabbits.

Results of ovarian histopathological photomicrograph of rabbits fed GRP supplemented diets are presented in Plate 1, 2, 3 and 4. Histopathological assessment of the ovaries revealed pictures of normal structural materials associated with complete oogenesis. The histological integrity of the ovary is fundamental to the

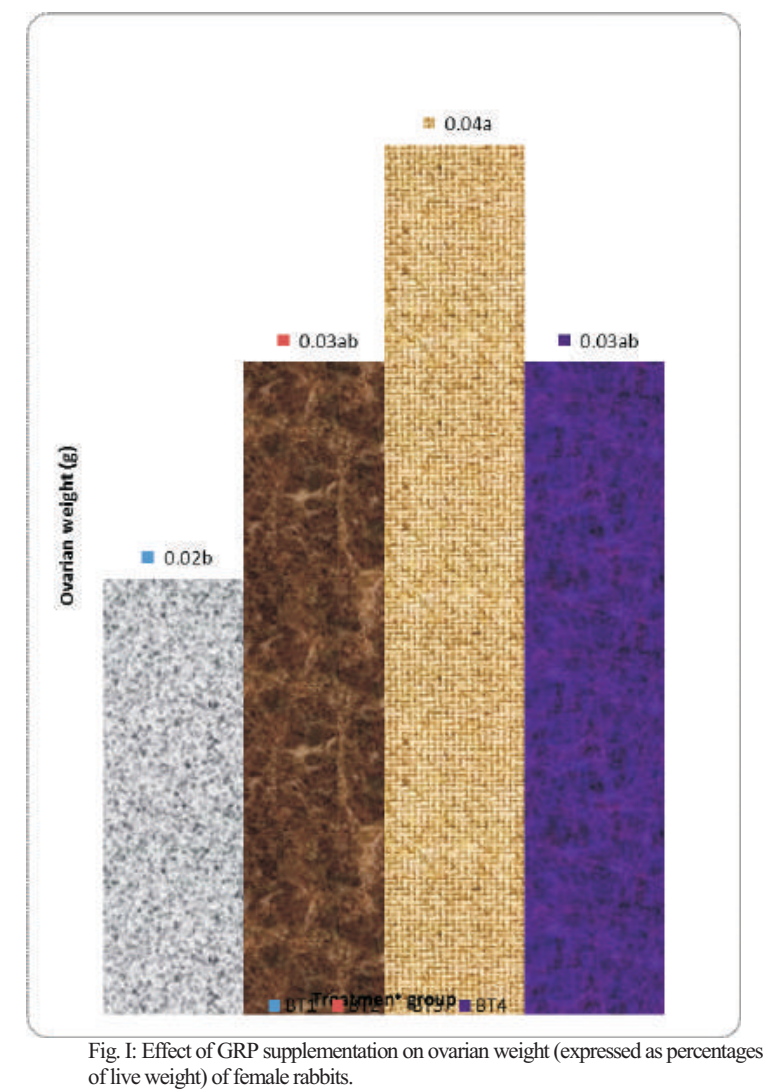




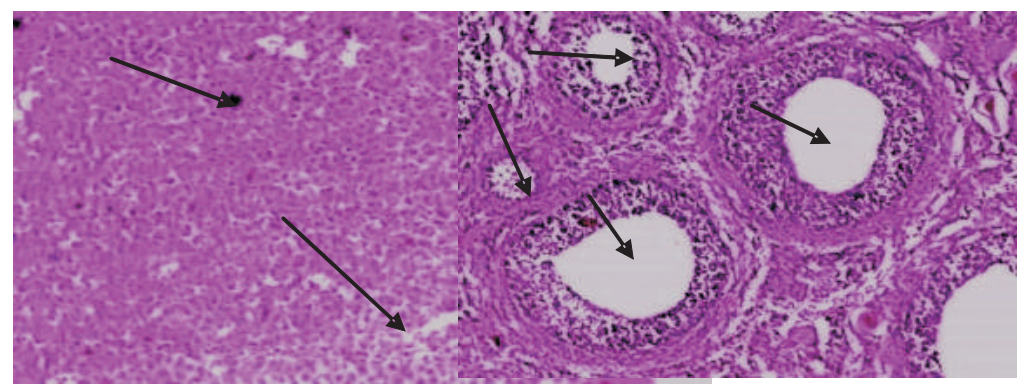

Plate 1: Transverse section in the ovary of $\mathrm{BT}_{1}$ females showing normal structure (H\& E X100)

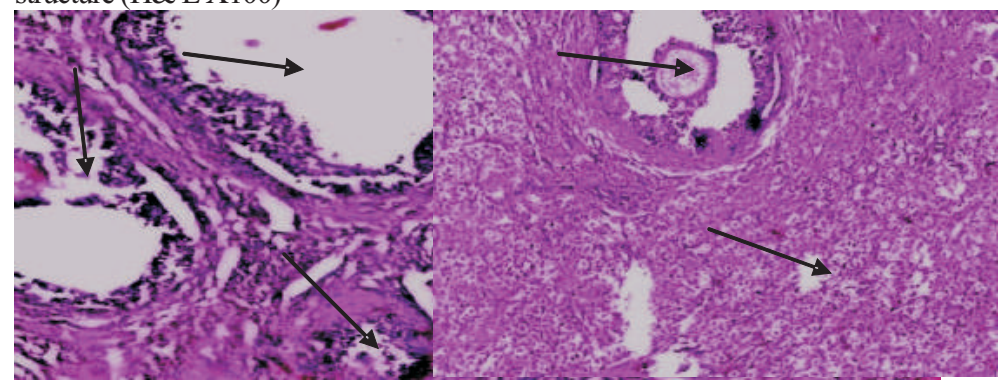

Plate 2: Transverse section in the ovary of $\mathrm{BT}_{2}$ females showing evidence of active follicular cells at different stages of development (H\& EX100)

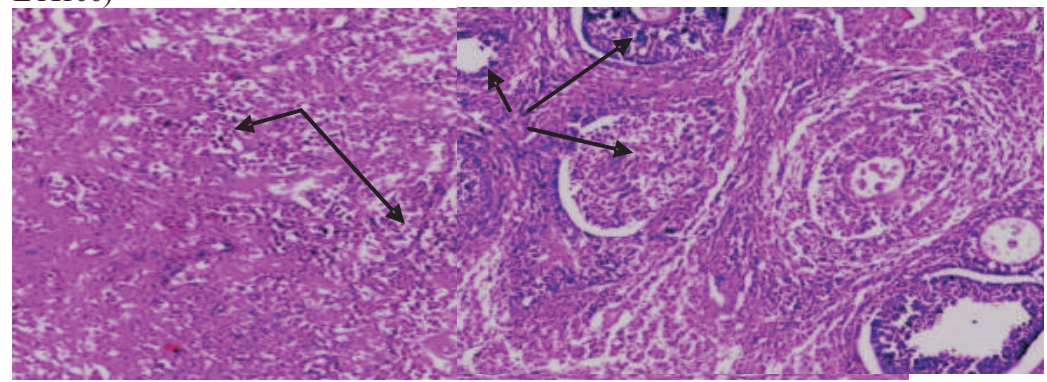

Plate 3: Transverse section in the ovary of $\mathrm{BT}_{3}$ females showing

evidence of active follicular cells at different stages of development (H\& EX100)

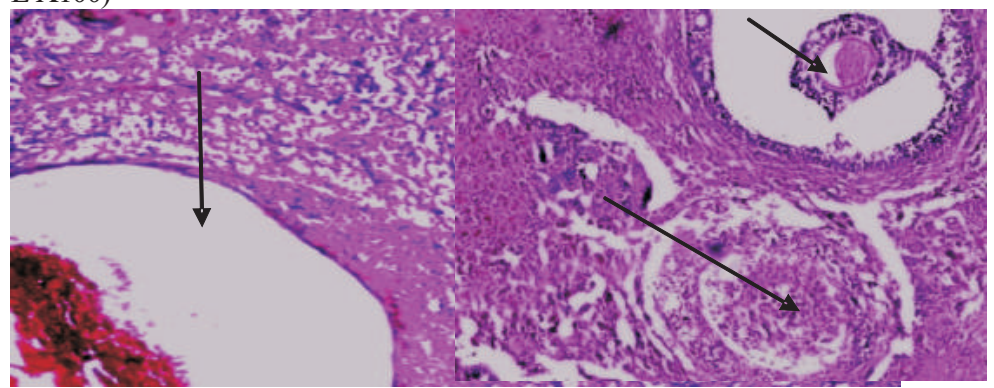

Plate 4. Transverse section in the ovary of $\mathrm{BT}_{4}$ females showing evidence of active follicular cells at different stages of development ( $\mathrm{H} \&$ EX100) 
production of fertile ova. Any factor (s), which damages the ovaries such as infections, toxic agents or malnutrition will result in the production of sub -fertile ova. Histological sections of the ovary in all the groups revealed normal ovary with numerous primordial follicles in the cortical areas. In this study, the pre-antral follicles were fully formed. The stroma was luteinized. All the ovarian tissues were suggestive of normal ovary with follicle development and ovulation. No lesions were observed, atretic follicles were less visible and normal olive green colour of ovaries was maintained. The present study revealed that groups fed ginger rhizome powder at 5, 10 and $15 \mathrm{~g} \mathrm{~kg}^{-1}$ feed had no evidence of histopathological alterations in the cytoarchiteture of the ovaries.

\section{Conclusion}

The result of ovarian morphometry revealed that ginger rhizome powder supplementation at 5,10 and $15 \mathrm{~g} \mathrm{~kg}^{-1}$ feed could improve the weight of the ovary indicating that up to $15 \mathrm{~g} \mathrm{~kg}^{-1}$ feed ginger rhizome powder supplementation would support better ovarian development in rabbits. This was associated with increased serum testosterone, progesterone and estrogen concentration indicating, probably a ginger rhizome powder inducement of improved metabolic activity. The current study also revealed that $10 \mathrm{~g} \mathrm{~kg}^{-1}$ feed was the optimal ginger rhizome powder supplementation rate in female rabbits, since this led to improved weight of ovary. This was equally associated with increased estrogen concentration, which decreased with increasing ginger rhizome powder supplementation.

\section{References}

Bartley, J. and Jacobs, A. 2000. Effects of drying on flavour compounds in Australian grown ginger (Zingiber officinale). Journal of the Science Food and Agriculture 80: 209 - 215.

Bitto, I.I. and Gemade, M. 2001. Preliminary investigations on the effects of paw paw peel meal on growth, visceral organs and endocrine gland weights, testicular morphometry and hematology of male rabbits. Global Journal Pure and Applied Science 7 (4): 621-625.

Bozkurt, M., Kucukyilmaz, K., Catli, A.U. and Cinar, M. 2008. Growth performance and slaughter characteristics of broiler chicken fed antibiotics, mannan oligosaccharide and dextran oligosaccharide supplemented diets. International Journal Poultry Science 7(10): 969 977.

Denli, M., Oka, F. and Celik, F. 2003. Effect of dietary probiotic, organic acids and antibiotic supplemented diets on broiler performance and carcass yield. Pakistan Journal of Nutrition 2(2): 89-99.

Drurry, K.A.B and Wallington, E.A. 1976. Histopathological Technique. $4^{\text {th }}$ Edition. pp: 48-58.

Hsia, S.M., Yeh, C.L., Kuo, Y.H., Wang, P.S. and Chiang, W. 2007. Effects of Adlay Hull extracts on the secretion of progesterone and estradiol in vivo and in vitro. Experimental Biology and Medicine 232 : 1181-1194.

Iwu, A.N., Ebere, C.S., Ogbuewu, I.P., Etuk, I.F., Opara, M.N., Uchegbu, M.C., Okoli, I.C., Iheukwumere, F.C. and Herbert, U. 2013. Coconut shell as a mild agonist of reproductive organ development and sex hormone release in growing rabbits. Journal of Medical Science 7: 563-570.

Micaleft, J.V., Hays, M.M., Latif, A., Alhasan, R. and Sufi, S. 1995. Serum 
binding of steroid tracers and its possible effects on direct steroid immunoassay. Annal Clinical Biochemistry 32 : 566-574.

Ogbuewu, I.P. 2008. Physiological responses of rabbits fed graded levels of neem (Azadirachta indica) leaf meal. MSc. Thesis, Federal University of Technology, Owerri. pp : 1-174.

Ogbuewu, I.P. 2012. Studies on the physiological responses of rabbits to ginger (Zingiber officinale) rhizome powder. Doctoral Thesis, Federal University of Technology, Owerri, pp. $1-302$.

Ogbuewu, I.P., Okoli, I.C. and Iloeje, M.U. 2013. The detrimental effect of dietary ginger rhizome powder supplementation on reproductive performance of pubertal rabbit bucks. International Journal of Innovation and Applied Studies 4 (1): 129-132.

Ogbuewu, I.P., Unamba-Opara, I.C., Odoemelam, V.U. Etuk, I.F. and Okoli, I.C. 2011. The potentiality of medicinal plants as the source of new contraceptive principle in males. A review. North American Journal Medical Science 3 (6): 255 263.

Ogbuewu, I.P., Omede, A.A., Chukwuka, O.K., Iheshiulor, O.O.M., Uchegbu, M.C., Udebuani, A.C., Ekenyem, B.C., Okoli, I.C. and Iloeje, M.U. 2010. The overview of the chemistry, health benefits and the potential threats associated with prolonged exposure to dietary soy isoflavones. A Review. International Journal of Agricultural Research 12: 1084-1099.

Osinowo, O.A. 2006. Introduction to Animal Reproduction. Sophie Academic Services Limited, Abeokuta, Nigeria 1st edition. pp: 91.

Osuagwu, O.M. 2004. Physiological responses of growing female rabbits to dietary supplementation of vitamin E. Project Report. Animal Science and Technology Department, Federal University of Technology, Owerri. pp. 52.

SAS 1999. Institute Inc. SAS Technical Report Package 234 SAS/STAT Software. The GEMOD Procedure. Release 6.09. SAS Institutes Inc. Cary, NC. USA.

Steel, R.G. and Torrie, J.H. 1980. Principles and procedures of statistics. An Approach. 2nd ed. McGraw Hill Book Co. Inc. New York.

Zhang, G.F., Yang, Z.B., Wang, Y., Jiang, S.Z. and Gai, G.S. 2009. Effects of ginger root processed to different particle sizes on growth performance, antioxidant status, and serum metabolites of broiler chickens. Poultry Science 88 : 2159 - 2166.

Zhao, X., Yang, Z.B., Yang, W.R., Wang, Y., Jiang, S.Z. and Zhang G.G. 2011. Effects of ginger root on laying performance and antioxidant status of laying hens and on dietary oxidation stability. Poultry Science 90: 1720 1727.

Received: 30 ${ }^{\text {th }}$ August, 2013 Accepted: $12^{\text {th }}$ September, 2014 